\title{
COMPLEX PARTIAL SEIZURES AND APHASIA AS INITIAL MANIFESTATIONS OF NON-KETOTIC HYPERGLYCEMIA
}

\author{
CASE REPORT
}

\author{
MARCUS SABRY AZAR BATISTA* DÉLRIO FAÇANHA SILVA**, \\ HENRIQUE BALLALAI FERRAZ***, LUIZ AUGUSTO FRANCO DE ANDRADE****
}

\begin{abstract}
We describe a case of non-ketotic hyperglycemia (NKH), heralded by complex partial seizures and aphasia of epileptic origin, besides versive and partial motor seizures. This clinical picture was accompanied by left fronto-temporal spikes in the EEG. The seizures were controlled by carbamazepine only after the control of the diabetes. A month later, carbamazepine was discontinued. The patient remained without seizures, with normal language, using only glybenclamide. Complex partial seizures, opposed to simple partial seizures, are rarely described in association to NKH. Epileptic activity localized over language regions can manifest as aphasia.
\end{abstract}

KEY WORDS: aphasia, seizures, diabetes mellitus.

\section{Crises parciais complexas e afasia como manifestações iniciais de hiperglicemia não cetótica: relato de caso}

RESUMO - Descrevemos um caso de hiperglicemia não-cetótica (HNC) cujas manifestações iniciais foram crises parciais complexas e afasia de origem epiléptica, além de crises versivas e parcias motoras. Este quadro clínico foi acompanhado por atividade epileptiforme na região fronto-temporal esquerda ao eletrencefalograma. As crises epilépticas foram controladas com carbamazepina (CBZ) apenas após o controle do diabetes mellitus. Após um mês, a CBZ foi suspensa, permanecendo a paciente com linguagem normal, sem novas crises epilépticas, em uso apenas de glibenclamida. Crises parciais complexas, ao contrário de crises parciais simples, são raramente descritas como manifestação de HNC. Atividade epileptiforme nas regiões relacionadas a linguagem podem manifestar-se como afasia.

PALAVRAS-CHAVE: epilepsia, crises epilépticas, diabetes mellitus, afasia.

Non-ketotic hyperglycemia (NKH) is classically associated to simple partial seizures and partial motor status epilepticus (SE) and rarely to complex partial seizures (CPS) $)^{1,2}$. We present a case that was heralded by CPS and aphasia of epileptic origin, before systemic signs and symptoms of diabetic decompensation.

\section{CASE REPORT}

A 60 year old black woman, right-handed, was brought by relatives to the neurological emergency room because of altered behaviour for a week. She presented irritation and moments of staring, that seemed to "turn off', stopping domestic work. At other times, she stopped speaking, or forgot the names of her relatives and objects, answering only monosyllables. Besides these episodes, she looked completely well. The patient and relatives denied other neurologic and systemic complaints, including fever, polyphagia, polydipsia, polyuria and

Escola Paulista de Medicina (EPM)/ Universidade Federal de São Paulo (UNIFESP): *Neurology resident; **Electroencephalographist; ***Neurologist; ****Professor, Neurology Department EPM/ UNIFESP. Aceite: 17-fevereiro-1998.

Dr. Marcus Sabry Azar Batista - Rua Napoleão de Barros 715 - 04024-002 São Paulo SP - Brasil. 


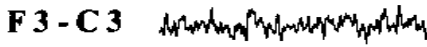

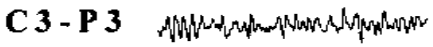

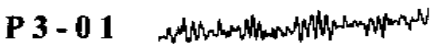

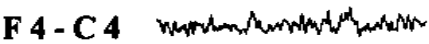

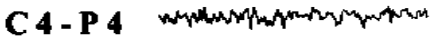

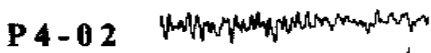

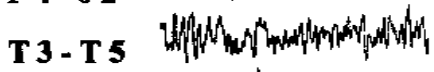

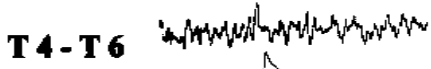

50 micro $V$ is

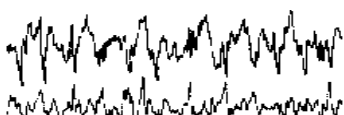

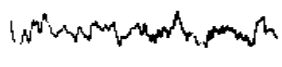

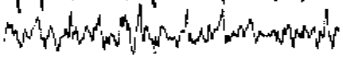
in
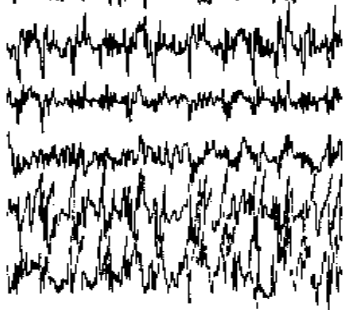

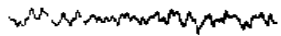
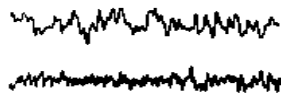

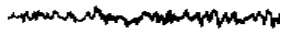

$\therefore '$

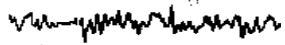

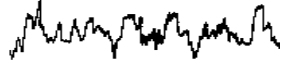

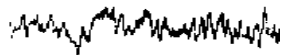

Fig 1. Epileptiform activity in the left fronto-temporal region.

weight loss. She had arterial hypertension, using propranolol irregularly, and diabetes mellitus, with no medication. She showed no abnormalities on general physical examination. Following this, however, she presented indifference and staring, answering only the jargon "eh, eh", attending inconsistently and with a long latency to verbal commands and presented gestual automatisms. She also presented episodes of staring and non responsiviness, followed by a tonic deviation of the head to the right and clonic seizures in the right hemiface. After that, the patient maintained difficult in finding names and a low fluency language for some minutes. She had at least 9 similar episodes, eyewitnessed by physicians. In the interictal period, there were no deficits other than motor aphasia and loss of temporo-spatial orientation.

The glycemia was $455 \mathrm{mg} / \mathrm{dl}$ and the seric $\mathrm{Na}^{+}$was $136 \mathrm{mEq} / \mathrm{l}$. There were no clinical or laboratorial evidences of infection. A cranial computed tomography (CT) scan without and with contrast resulted normal. A transthoracic echodopplercardiogram showed no abnormalities. A carotid and vertebral doppler ultrasonography showed a medio-intimal thickening in the carotid arteries, bilaterally, and a plaque in the right carotid. A cerebrospinal fluid (CSF) analysis showed 8 lymphomonocytary cells and a glycorrachia of $130 \mathrm{mg} / \mathrm{dl}$. An electroencephalogram (EEG) (Fig 1) showed epileptiform activity initiated in the posterior left temporal region, with recruiting activity, irradiated to the left frontal region, with a subsequent generalization, with spike and wave complexes. Even using 1,200 mg of carbamazepine (CBZ), the patient maintained very frequent similar episodes, that ceased only after a metabolic control with insulin.

The patient persisted for 2 days with low fluency speech, with difficulty in finding names and omitting prepositions - but maintaining a normal comprehension and attending normally to all verbal commands. She was discharged after 3 days without seizures and with normal speech. An EEG, immediately before the discharge, and another one month later, resulted normal. The patient presented no more seizures nor language alterations and, one month after discharge, the CBZ was withdrawn, using only glybenclamide.

\section{DISCUSSION}

We considered the patient's staring and gestual automatisms as CPS. The motor aphasia persisted for two days even after controlling the seizures. The episodic presentation, just as the EEG findings and the normality of the CT scan indicated that the aphasia, together with the CPS, were due to recurring epileptic activity localized near language areas.

Even with a diffuse insult to the central nervous system (CNS), clinical manifestations may originate in a specific region. Hyperglycemia has been associated with symptoms of focal neurological dysfunction such as hemianopsias, hemiballism, hemichorea and choreo-athetosis ${ }^{3-6}$. Generally, 
patients had previous structural lesions in the areas related to these symptoms, perhaps making them more susceptible. The hippocampal regions CA1, CA3 and CA4 are very susceptible to ischemia and metabolic disturbances. Furthermore, systemic administrated agents, like pilocarpine or kainic acid, can produce non-convulsive SE, in the form of "limbic" seizures ${ }^{7-10}$. So, limbic regions could be selectively injured, even in a generalized CNS insult, originating the epileptic activity that can lead to CPS. If it really happens, a much higher frequency of this kind of seizure in NKH would be expected than is actually recognized.

The CPS may present as a confusional state and sometimes with subtle manifestations, being difficult to diagnosis. Usually all the clinical pictures is attributed to the precipitating factor ${ }^{11}$. We can hypothesize that because of this, the reported frequency of CPS is so low. It is very important to recognize this association, due to considerable morbidity, including neurologic sequelae, and even mortality as a result of lasting, non treated seizures ${ }^{11}$. The case we present, however, was heralded by neurological manifestations, facilitating its diagnosis. It is very well established that aphasia can be the initial, only and sometimes progressive manifestation of epilepsy and focal SE ${ }^{2,11-14}$. Other focal signs, like amaurosis, disartria, speech arrest may manifest localized seizures ${ }^{15-17}$.

In this patient, we may think that the aphasia could have resulted from a stroke. The hyperosmolarity, leading to elevation of blood viscosity could facilitate a vascular injury ${ }^{6,8}$. The patient showed no abnormalities in the pre and post-contrast CT scans. However, magnetic resonance imaging (MRI) would be more precise to identify small vascular lesions. Nevertheless, the initially paroxysmal character of the aphasia, its short time course (two days) in close temporal association to CPS and to clonic seizures in the right hemiface and also the EEG findings over regions related to language, very strongly suggest that the aphasia was of epileptic - not of vascular - origin. Embolization from the atheromatous plaque of the right carotid, might not be associated to the aphasia, since in right-handed persons, the dominant hemisphere for language is the left in $99 \%$ of times ${ }^{18}$.

The versive component of our patient's seizures, to the right, agrees with the left frontal origin of the epileptic activity, just as the clonic component in the right hemi-face. Besides, the EEG showed epileptic activity over this same region, responsible for language ${ }^{19}$.

The moderate CSF cellularity we found in this case can be explained by the very frequent seizures, associated to the high seric osmolarity ${ }^{20}$.

So, we admit that the aphasia occurred due to a compromise of regions specialized in language because of repeated localized epileptic seizures, precipitated and aggravated by the metabolic dysfunction ${ }^{7,8,21}$. It had persisted for two days after the seizures control, like a Todd's phenomenon, prolonged because of the unfavorable metabolic local environment. Focal SE produces such a severe localized metabolic dysfunction that may lead to cerebral edema detectable by CT scans and MRI, reversible with seizure control ${ }^{22}$.

We considered that NKH could have facilitated epileptic activity. In the case described, due to its localization in the left fronto-temporal region, it led to CPS, partial motor and versive seizures and aphasia. CPS and aphasia must be remembered as possible initial clinical manifestations of NKH.

\section{REFERENCES}

1. Grant C, Warlow C. Focal epilepsy in diabetic non-ketotic hyperglycaemia. Br Med J 1985;290:1204-1205.

2. Manford M, Fuller GN, Wade JPH. "Silent diabetes": non-ketotic hyper-glycaemia presenting as aphasic status epilepticus (Letter). J Neurol Neurosurg Psychiatry 1995;59:99-100.

3. Lin JJ, Chang MK. Hemiballism-hemichorea and non-ketotic hyperglycaemia. J Neurol Neurosurg Psychiatry 1994;57:748-750.

4. Rector WG, Herlong F, Moses H III. Nonketotic hyperglycemia appearing as choreoathetosis or ballism. Arch Intern Med 1982;142:154-155. 
5. Singh BM, Strobos RJ. Epilepsia partialis continua associated with non-ketotic hyperglycemia: clinical and biochemical profile of 21 patients. Ann Neurol 1980;8:155-160.

6. Windebank AJ, McEvoy KM. Diabetes and the nervous system. In Aminoff MJ (ed). Neurology and general medicine. 2.Ed. New York: Churchill Livingstone 1995:367-374.

7. Longstreth WT Jr. Neurological complications of cardiac arrest. In Aminoff MJ (ed). Neurology and general medicine. 2.Ed. New York: Churchill Livingstone 1995:159-182.

8. Jordan KG. Neurophysiologic monitoring in the neuroscience intensive care unit. Neurol Clin 1995;13:567-594.

9. Vastola EF, Maccario M, Homen R. Activation of epileptogenic foci by hyperosmolality. Neurology 1967;17:520-526.

10. Lothman E. The biochemical basis and pathophysiology of status epilepticus. Neurology 1990;40(Suppl 2):13-23.

11. Krumholz A, Sung GY, Fischer RS, Barry E, Bergey GK, Grattan LM. Complex partial status epilepticus accompanied by serious morbidity and mortality. Neurology 1995;45:1499-1504.

12. Hamilton GN, Matthews T. Aphasia: the sole manifestation of focal status epilepticus. Neurology 1979;29:745-748.

13. Lesser RP. Aphasia as the initial manifestation of epilepsy. Mayo Clin Proc 1991;66:325- 326.

14. Murchison JT, Sellar RJ, Steers AJW. Status epilepticus presenting as progressive dysphasia. Diagnostic Neuroradiol 1995;37:438-439.

15. Cascino GD, Westmoreland BF, Swanson TH, Sharbrough FW. Seizure associated speech arrest in elderly patients. Mayo Clin Proc 1991;66:254-258.

16. Gilliam F, Wyllie E. Ictal amaurosis: MRI, EEG and clinical features. Neurology 1995;45:1619-1621.

17. Shafrir Y, Prenky AL. Aquired epileptiform opercular syndrome: a second case report, review of the literature, and comparison to the Landau-Kleffner syndrome. Epilepsia 1995;36:1050-1057.

18. Haerer AF. Aphasia, agnosia and apraxia: examination of language and related functions. In De Jong's The Neurologic Examination. 5.Ed. Philadelphia: JB Lippincott, 1992:659-666.

19. Wyllie E, Lüders H, Morris HH, Lesser RP, Dinner DS. The lateralizing significance of versive head and eye movements during epileptic seizures. Neurology 1986;36:606-611.

20. Barry E, Hauser A. Pleocytosis after status epilepticus. Arch Neurol 1994;51:190-193.

21. Mel'nichuk PV, Zenkov LP, Morozov AA, Kogan EI, Averyanov YN. Neurophysiological mechanisms of aphasia in epilepsy. Zhurnal Nevropatologii i Psikhiatrii imeni S.S. Korsakova 1990;90:34-40.

22. Kirshner HS, Hughes T, Fakhoury T, Abou-Khalil B. Aphasia secondary to partial status epilepticus of the basal temporal language area. Neurology 1995;45:1616-1618. 